\title{
PENGENALAN POLA TULISAN TANGAN AKSARA ARAB MENGGUNAKAN METODE CONVOLUTION NEURAL NETWORK
}

\author{
(Handwritten Arabic Script Recognition Using Convolution Neural Network ) \\ Nanang Kasim*, Gibran Satya Nugraha \\ Program Studi Teknik Informatika, Fakultas Teknik, Universitas Mataram \\ JI. Majapahit 62, Mataram, Lombok NTB, INDONESIA \\ Email: nanangk.ti16@gmail.com, gibransn@unram.ac.id
}

\begin{abstract}
Arabic is the language found in the holy book Al-Qur'an. Learning Arabic with the concept of letterforms is a very effective method. The recognition of Arabic script handwriting patterns is one of the previous studies, where the accurate results can vary according to the research method used. This study aims to build a machine learning model and the resulting accuracy of handwriting Arabic script recognition using convolution neural network, and to correct some of the deficiencies in previous research. Convolution neural network is a classification method by providing labels when learning or classified as supervised learning. The data used for this research is data that comes from handwriting on A4 HVS paper using markers with two categories, namely ages 5 to 20 years and ages 20 years and over in order to get handwriting variations. Model testing is carried out on research data and previous research data. The research produced an architectural model with 3 convolution layers each with 128 filters, $5 \times 5$ kernel size, $1 \mathrm{HL}$ each layer with 128 neurons, 30\% dropout weight, 0.001 learning rate, 64×64 image size, normalization with ReLU activation function, and 1 input image dimension, comparison of testing data and training 70:30, and accuracy is $78.10 \%$.
\end{abstract}

Keywords: pattern recognition, handwriting, Arabic script, convolution neural network, machine learning

*Penulis Korespondensi

\section{Pendahuluan}

Bahasa Arab tersusun atas susunan huruf Arab / huruf Hijaiyah yang terdapat pada Al-Qur'an. Al Qur'an adalah kitab suci bagi pemeluk agama Islam yang wajib dipelajari, dan setiap Muslim wajib bisa membaca AlQur'an serta bisa mengenali tiap-tiap huruf Hijaiyah yang menyusunnya[1].

Faktanya salah satu metode belajar bahasa Arab yang mudah adalah dengan mengenali bentuk hurufnya, yang nantinya akan dibuat aplikasi yang mampu mengidentifikasi tulisan tangan aksara Arab yang ditulis user. Cara ini cukup efisien mengingat di saat ini banyak yang lebih suka bergaul dengan gadgetnya[2]

Pengenalan pola adalah mengelompokkan data numerik dan simbolik (seperti citra) secara otomatis oleh mesin (komputer). Tujuan pengenalan pola yaitu untuk mengenali suatu objek yang ada dalam citra digital.

Dalam melakukan pengenalan pola bisa dilakukan dengan berbagai metode seperti convolutional neural network (CNN) yang telah banyak digunakan dan mendapatkan hasil yang baik. Beberapa penelitian yang telah menggunakan metode convolution neural network dengan akurasi yang baik antara lain pengenalan huruf dan angka tulisan tangan menggunakan metode convolution neural network dengan akurasi $83 \%[3]$, convolutional neural networks untuk pengenalan wajah secara real-time dengan akurasi $87.48 \%[4]$, implementasi deep learning menggunakan convolution neural network untuk klasifikasi alat tulis, klasifikasi alat tulis yang dimaksud disini adalah melakukan pengenalan pada alat tulis seperti bolpoint, pensil, penghapus dan penggaris, dengan akurasi 95\%[5], dan pengenalan tulisan tangan pada lembar ujian pilihan ganda menggunakan metode convolution neural network dengan akurasi 94.3\%[6].

Aksara Arab memiliki beberapa sifat ortografik dan morfologis yang membuat pengenalan tulisan tangan aksara Arab menjadi menantang[7]. Selain itu, salah satu tantangan terbesar dalam pengenalan pola aksara Arab adalah berbedanya gaya tulisan tangan dan karakter tulisan setiap orang[8]. Penelitian pengenalan pola aksara Arab menggunakan metode convolution neural network juga pernah dilakukan sebelumnya. Penelitian tersebut yaitu arabic handwritten characters recognition using convolutional neural network yang 
pernah dilakukan di Mesir[9]. Penelitian tersebut mempunyai beberapa kekurangan antara lain kurangnya variasi dataset yang digunakan. Dataset yang digunakan diambil secara acak dari tulisan 60 orang dengan rentang usia 19 sampai 40 tahun sehingga variasi dataset hanya dari tulisan tangan orang dewasa saja. Kekurangan yang kedua yaitu kurangnya skenario uji yang diterapkan. Model hanya dibangun dengan satu arsitektur model saja dan satu ukuran gambar yaitu $32 \times 32$ piksel sehingga tidak dapat diketahui apakah pengaruh dimensi gambar, jumlah hidden layer, jumlah neuron hidden layer, batas epoch, ukuran matriks kernel, jumlah filter konvolusi, learning rate, perbandingan data training dan data testing, dan bobot dropout yang diterapkan terhadap akurasi model[9].

Berdasarkan pemaparan tersebut, penulis mengajukan penelitian untuk merancang sebuah model pembelajaran mesin (machine learning) untuk mengenali pola tulisan tangan aksara. Penelitian ini menerapkan metode convolutional neural network (CNN) dengan memperbaiki beberapa kekurangan pada penelitian sebelumnya seperti variasi dataset yang hanya menggunakan satu variasi dataset. Mengingat kurangnya skenario uji pada penelitian sebelumnya, maka penerapan skenario uji akan diterapkan pada penelitian ini, scenario uji yang diterapkan yaitu Keluaran dari penelitian ini diharapkan dapat membantu pembuatan sistem pembelajaran aksara melalui tulisan tangan digital dan membantu dalam proses pembelajaran bahasa Arab.

\section{Tinjauan PUSTAKa}

Convolution neural network (CNN) merupakan metode klasifikasi dengan memberikan label pada saat melakukan pembelajaran atau tergolong ke dalam supervised learning. Secara umum, CNN memiliki dua buah layer dalam model pengenalan polanya yaitu layer ekstraksi fitur dan layer klasifikasi. Layer ekstraksi fitur terdiri dari layer konvolusi dan layer klasifikasi terdiri dari layer multi-layer perceptron. Alex Krizhevsky pada tahun 2012 berhasil menjuarai kompetisi dengan penerapan CNN miliknya di mana prestasi tersebut menjadi momen pembuktian bahwa metode CNN berhasil mengungguli metode machine learning lainnya seperti SVM pada kasus klasifikasi objek pada citra [10]. Metode CNN juga sudah terbukti memiliki akurasi yang sangat baik dan dapat menangani data yang sangat banyak. Pada tahun 2012, CNN dapat melakukan pengenalan citra dengan akurasi yang menyaingi manusia pada dataset tertentu. Metode Machine Learning yang saat ini memiliki hasil paling signifikan dalam pengenalan citra adalah Convolutional Neural
Network (CNN). Hal tersebut dikarenakan CNN berusaha meniru sistem pengenalan citra pada visual cortex manusia sehingga memiliki kemampuan mengolah informasi citra[11].

Penelitian mengenai pengklasifikasian suatu citra menggunakan metode convolution neural network sudah pernah dilakukan oleh beberapa peneliti dalam kurun waktu 5 tahun belakangan ini. Penelitianpenelitian sebelumnya akan dijadikan sebagai rujukan ketika pelaksanaan penelitian ini.

Penelitian tentang aksara Arab sebelumnya telah dilakukan beberapa kali. Penelitian-penelitian yang dimaksud antara lain pengenalan tulisan tangan bahasa arab menggunakan metode probabilistic neural network [12], identifikasi citra huruf arab menggunakan metode jaringan syaraf tiruan kohonen [1], pengenalan pola huruf hijaiyah khat kufi dengan metode deteksi tepi sobel berbasis jaringan syaraf tiruan backpropagation [13].

Penelitian tentang klasifikasi menggunakan metode convolution neural network sudah pernah dilakukan beberapa kali pada interval tahun 2016-2019. Penelitian-penelitian tersebut antara lain pengenalan huruf dan angka tulisan tangan [3], pengenalan wajah secara real-time [4], klasifikasi alat tulis [5], dan klasifikasi tingkat retakan pada bangunan berbasis citra [14], dan Penelitian pengenalan pola tulisan tangan huruf Arab menggunakan metode CNN juga pernah dilakukan di Mesir[9].

Berdasarkan penelitian-penelitian yang sudah dilakukan sebelumnya, dapat dilihat bahwa convolution neural network dapat bekerja dengan baik untuk pengklasifikasian citra dengan dataset yang banyak. Oleh karena itu, penulis bermaksud untuk menggunakan metode ini untuk mengenali tulisan tangan aksara Arab.

\section{Metode Penelitian}

\subsection{Diagram Alir Penelitian}

Diagram alir di atas memperlihatkan bahwa proses perancangan penelitian dimulai dari langkah awal yakni studi literatur. studi literatur disini yaitu untuk mempelajari cara membangun model machine learning yang sesuai sesuai dengan metode yang digunakan. Langkah kedua yakni pengumpulan dataset disini artinya proses pengumpulan citra yakni aksara Arab dengan 28 karakter. Proses pengambilan citra aksara berdasarkan 2 kategori, yaitu usia 5 sampai 20 tahun dan usia 20 tahun ke atas baik yang sudah pernah belajar aksara Arab maupun belum pernah belajar aksara Arab. Selanjutnya yakni tahap pembangunan model sesuai dengan rancangan yang telah dibuat. 
Tahap pengujian model dilakukan untuk menguji apakah model yang telah dibuat sudah sesuai dengan tujuan. Model dikatakan sesuai jika model sudah mampu melakukan training pada dataset aksara yang ada, mampu melakukan proses klasifikasi pada suatu data baru, dan mengklasifikasikan data baru tersebut ke suatu kelas tertentu yang ada. Jika tidak, maka proses akan kembali ke tahap perancangan model, dan jika sesuai maka proses akan dilanjutkan ke tahap terakhir yakni pembuatan laporan penelitian. Pada penelitian ini penetuan akurasi bergantung pada seluruh skenario pelatihan yang dirancang untuk mendapatkan arstiketur model convolution neural network yang terbaik.

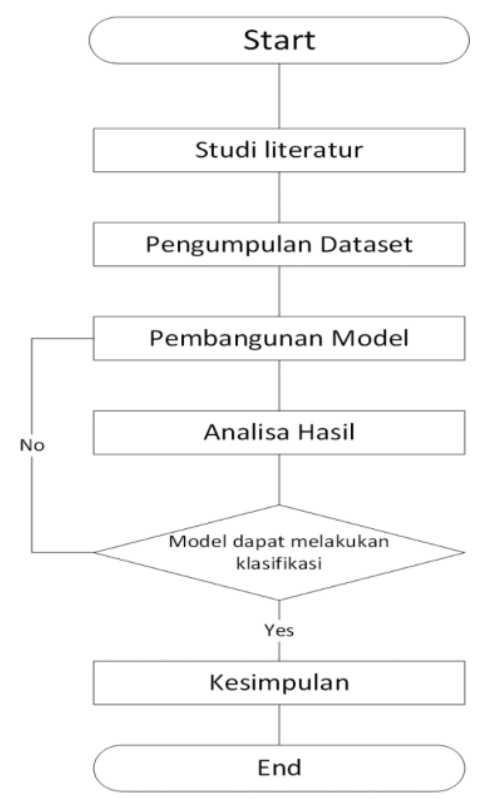

Gambar 1. Diagram alir proses penelitian

\subsection{Persiapan Dataset}

Pengambilan citra aksara Arab menggunakan template dari kolom tabel dengan tinggi dan lebar yang di setting $4 \mathrm{~cm} \times 4 \mathrm{~cm}$ dengan banyak kotak sebanyak 28 kotak atau tabel sesuai dengan jumlah karakter aksara Arab yaitu 28 buah. Kertas yang digunakan seragam yaitu HVS A4. Template pengambilan data tersebut menjadi empat baris dan tujuh kolom yang nantinya akan ditulis oleh sumber menggunakan spidol berupa tulisan tangan. di tulis oleh kalangan SD, SMP, SMA, Kuliah, dan Masyarakat Umum dengan total melibatkan sebanyak 30 orang serta dibedakan berdasarkan dua jenis yaitu usia 5 sampai 20 tahun dan usia 20 tahun ke atas baik yang sudah pernah belajar aksara Arab maupun belum pernah belajar aksara Arab. Untuk proses pengambilan data satu orang memberikan kontribusi sebanyak 10 kali penulisan. Hal ini dilakukan untuk mendapatkan data latih yang banyak dan variatif maka hasil yang didapatkan semakin bagus karena classifier dalam hal ini convolution neural network melakukan banyak pembelajaran/pelatihan. Data yang terkumpul sebanyak 8400 citra. Data yang terkumpul lalu di scan dengan dengan resolusi tinggi. Pada penelitian sebelumnya terdapat 16800 data yang terkumpul dengan sistematika pengambilan data yang sama yaitu dengan menggunakan tulisan tangan manual[9]. Data ini akan digunakan sebagai data pembanding pada saat proses pelatihan dan klasifikasi citra

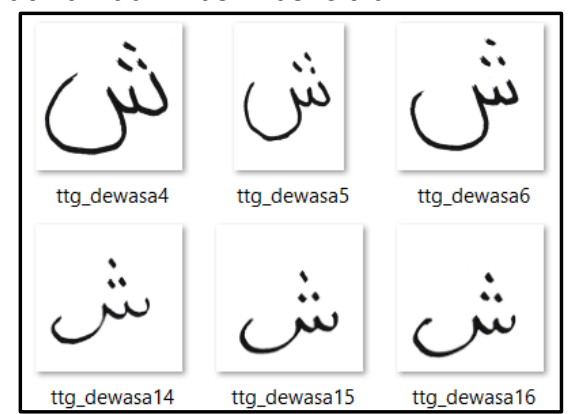

Gambar 2. Contoh citra aksara Arab yang diambil oleh peneliti

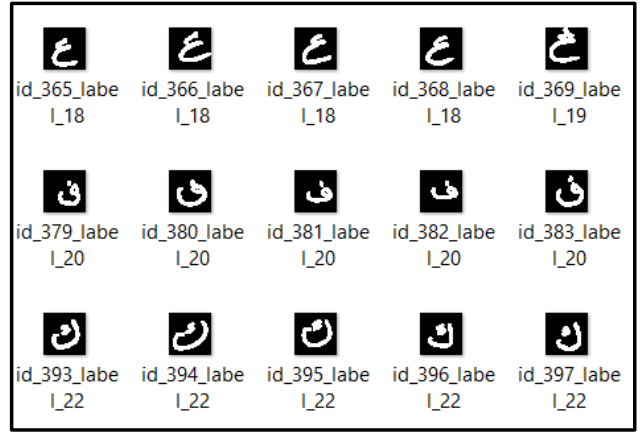

Gambar 3. Contoh citra aksara Arab dari penelitian sebelumnyai[9]

\subsection{Pembuatan Model Convolution Neural Network}

Penelitian ini akan menggunakan metode convolution neural network untuk melakukan pengenalan pola pada tulisan tangan aksara Arab. Penelitian ini terbagi menjadi dua tahap. Pertama adalah tahap pelatihan (training) dan yang kedua adalah tahap pengujian (testing). Tahap pelatihan merupakan tahap dimana akan dilakukan pengolahan citra dari data latih untuk dibuatkan model klasifikasi dengan menggunakan metode convolution neural network. Sedangkan untuk tahap pengujian merupakan tahapan untuk menguji model convolution neural network yang dibangun pada tahap pelatihan dengan masukan citra dari data uji. Lebih jelasnya, alur klasifikasi dapat dilihat pada Gambar 4. 


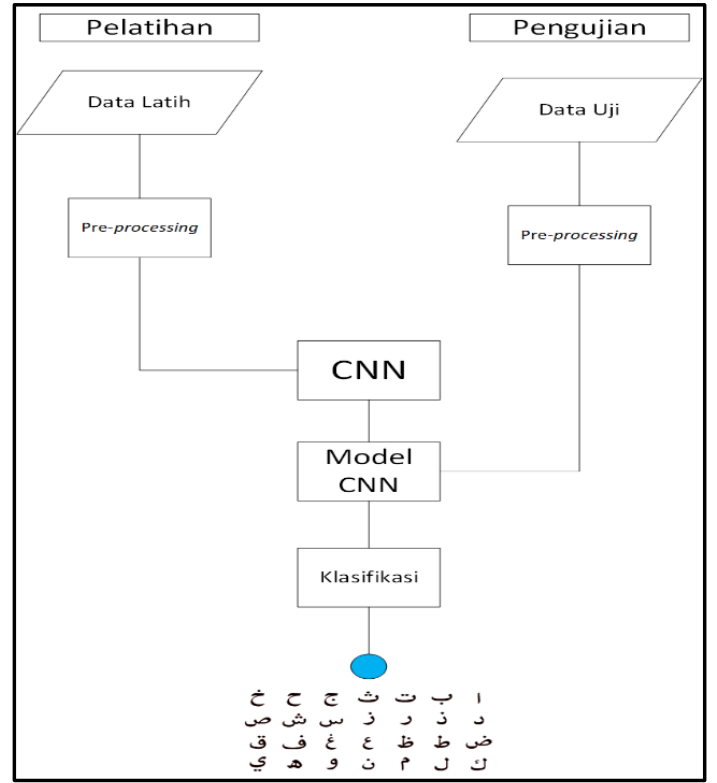

Gambar 4. Alur klasifikasi convolution neural network

\subsubsection{Preprocessing}

Pre-processing dilakukan untuk memperbaiki citra agar citra yang diolah memiliki hasil yang optimal. Citra dataset terlebih dahulu akan disamakan ukurannya dengan melakukan resizing terhadap citra. Ukuran yang digunakan dalam penelitian ini adalah $128 \times 128$, $64 \times 64$ dan $32 \times 32$ sehingga bisa melihat pengaruh size citra terhadap penelitianm semakin kecil piksel citra maka proses training akan semakin cepat. Selanjutnya, citra yang sudah di resize akan di rubah dimensi warnanya dari RGB menjadi grayscale. Perubahan bertujuan agar citra menjadi matriks dengan 1 dimensi warna sehingga dapat diteruskan ketika melakukan pemrosesan pada layer konvolusi[15].

\subsubsection{Model Convolution Neural Network}

\section{Input citra}

Citra yang telah di-input akan di representasikan ke dalam matriks citra 2 dimensi supaya citra bisa memasuki tahapan feature learning[15].

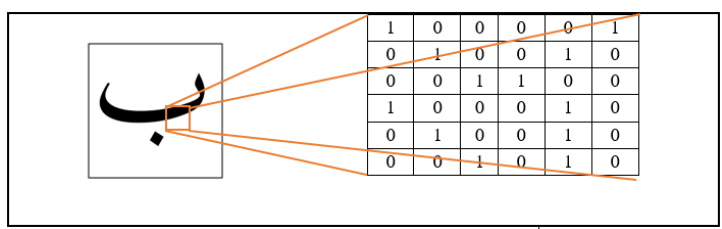

Gambar 5. Representasi citra menjadi matrix

2. Convolution

Layer konvolusi bertujuan untuk mem-filter matriks dari citra input[5][16], ukuran matriks yang telah melalui layer konvolusi ukurannya akan berkurang sehingga diperlukan zero padding untuk mempertahankan ukuran matriks citra[14]. Proses pada layer konvolusi menggunakan matriks kernel $3 \times 3$ dan $5 \times 5$, pemilihan dua ukuran kernel yang berbeda bertujuan ntuk mengetahui pengaruh ukuran matriks kernel terhadap penelitian yang dilakukan. Output dari layer konvolusi ini kemudian akan menjadi masukan pada layer polling[17].

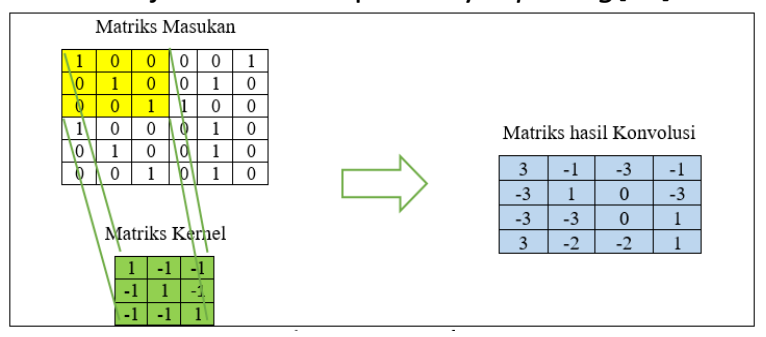

Gambar 6. Proses convolusi

Hasil perhitungan pada layer konvolusi yang berniai negatif akan dilakukan perhitungan tambahan untuk menghilangkan nilai negatif pada matriks citra. Pada penelitian ini pendekatan perhitungan yang akan digunakan adalah pendekatan fungsi aktivasi ReLU. Fungsi aktivasi ReLU akan mengubah nilai matriks yang bernilai negatif menjadi 0 [18][19]. Fungsi aktivasi ReLU sudah banyak digunakan pada penelitian dengan metode convolution neural network sebelumnya dan mendapat performa yang baik.

\begin{tabular}{|c|c|c|c|c|c|c|c|c|}
\hline \multicolumn{4}{|c|}{ Matriks masukan } & & \multicolumn{4}{|c|}{ Matriks setelah ReLU } \\
\hline 3 & -1 & -3 & -1 & \multirow{4}{*}{$\stackrel{\mathrm{ReLU}}{\longrightarrow}$} & 3 & 0 & 0 & 0 \\
\hline-3 & 1 & 0 & -3 & & 0 & 1 & 0 & 0 \\
\hline-3 & -3 & 0 & 1 & & 0 & 0 & 0 & 1 \\
\hline 3 & -2 & -2 & 1 & & 3 & 0 & 0 & 1 \\
\hline
\end{tabular}

Gambar 7. Aktivasi ReLU

3. Max Pooling

Layer pooling akan mengurangi ukuran citra sehingga proses feature map menjadi lebih cepat[17]. Pooling pada penelitian ini menggunakan matriks $2 \times 2$ dengan stride sebesar 2. Artinya, pooling akan bergeser sebanyak 2 indeks dan mencari nilai terbesar dari pooling atau bisa disebut dengan istilah max pooling

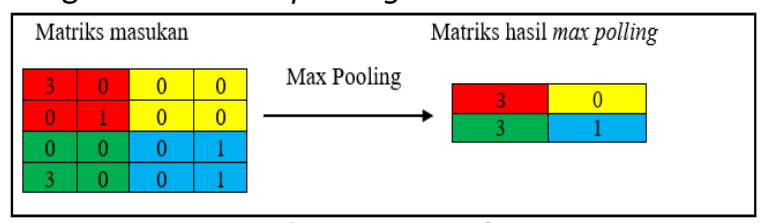

Gambar 8. Proses max polling

4. Flatten

Flatten merupakan proses dimana matriks hasil feature learning (konvolusi dan polling) dirubah menjadi vektor yang selanjutnya menjadi masukan dalam proses klasifikasi dengan arsitektur fully connected layer. Flatten diterapkan untuk mengubah matriks menjadi vektor untuk 
menyesuaikan dengan format masukan pada layer neural network.

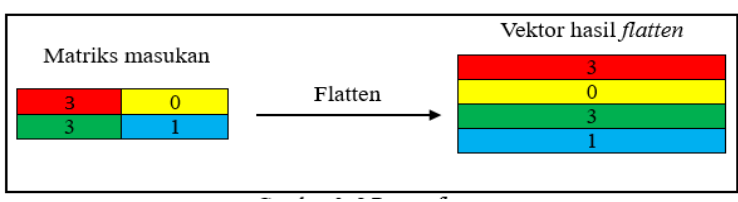

Gambar 9. Proses flatten

5. Fully Connected Layer dengan dropout

Penelitian ini akan menggunakan tiga jumlah hiden layer yang berbeda yaitu 1 hiden layer, 2 hiden layer dan 3 hiden layer untuk mengetahui pengaruh jumlah hiden layer dalam penelitian. Masing masing layer akan memiliki 64 neuron. Untuk mengurangi kemungkinan terjadinya overfitting maka pada model akan diterapkan dropout[16]. Penelitian ini akan menerapkan dropout dengan bobot $20 \%$ yang artinya akan memilih secara acak neuron di tiap layer sebanyak $20 \%$ untuk dinonaktif-kan

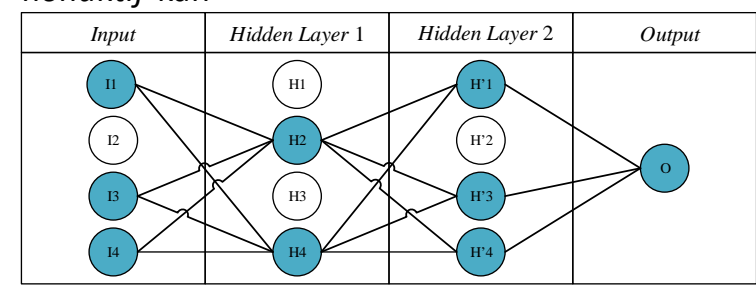

Gambar 10. Fully connected layer dengan dropout

\subsection{Evaluasi Model}

Evaluasi model merupakan tahapan untuk mengevaluasi model apakah berjalan dengan baik dan benar serta untuk mengetahui kekurangan model jika terjadi kesalahan dalam proses pengujian. Dalam pengujian sistem dilakukan perhitungan akurasi, precisi, dan recall menggunakan persamaan 3-1, 3-2, dan 3-3:

$$
\text { Akurasi }=\frac{\text { jumlah data sesuai target }}{\text { Total keseluruhan data }}
$$

Presisi $=\frac{\text { jumlah data yang sesuai target di satu kelas }}{\text { jumlah seluruh data yang sesuai target }}$ (2)

Recall $=\frac{\text { jumlah data yang sesuai target di satu kelas }}{\text { jumlah data di satu kelas }}$

\section{Hasil dan Pembahasan}

\subsection{Skenario Pengujian}

Ada beberapa tahapan yang dilakukan pada penelitian ini untuk mendapatkan model terbaik. Tahapan pertama yang dilakukan adalah merekayasa penggunaan jumlah dataset untuk melakukan pengujian model terbaik. Dataset yang digunakan untuk pencarian model ini adalah dataset yang diambil oleh peneliti sebanyak 8400 citra data.

Selanjutnya, dilakukan pengujian terhadap model machine learning yang dibangun menggunakan dataset yang sudah disebutkan sebelumnya. Pengujian ini dilakukan dengan berbagai parameter dengan urutan pengujian sebagai berikut.

1. Ukuran kernel konvolusi (kernel $3 \times 3$ dan kernel $5 \times 5$ )

2. Jumlah filter konvolusi $(32,64$, dan 128)

3. Jumlah hidden layer neural network $(1 \mathrm{HL}, 2 \mathrm{HL}$, dan $3 \mathrm{HL})$

4. Ukuran neuron hidden layer (32 neuron, 64 neuron, dan 128 neuron)

5. Jumlah bobot dropout (20\%, 30\%, dan $50 \%)$

6. Bobot learning rate $(0.01,0.001$, dan 0.0001$)$

7. Perbandingan data training dan testing (70:30 dan 80:20)

8. Ukuran citra masukan $(32 \times 32,64 \times 64$, dan $96 \times 96)$

9. Batas epoch training data $(100,500$, dan 1000)

Model terbaik yang didapatkan dari hasil pengujian dengan dataset dari peneliti selanjutnya diuji terhadap tiga jenis dataset. Ketiga jenis dataset tersebut yaitu dataset yang diambil oleh peniliti berjumlah 8400 dengan ukuran citra bervariasi, dataset penelitian sebelumnya 16800 dengan ukuran citra 32 x 32 dan dataset gabungan dari keduanya berjumlah data 8400 dan 16800. Tahapan ini yang dilakukan adalah membandingkan hasil dari ketiga jenis dataset yaitu dataset yang diambil oleh peneliti dan dataset yang diperoleh dari penelitian sebelumnya serta dataset gabungan dari kedua jenis dataset yang digunakan. Pengujian ini dilakukan untuk melihat pengaruh perlakuan data yang berbeda pada tulisan aksara sasak dengan karakter yang sama serta menguji peforma model terhadap data yang baru yaitu pada data 16800 dari penelitian sebelumnya[9].

\subsection{Hasil Pengujian Terhadap Ukuran Kernel}

Kernel merupakan matrix yang menjadi pengali untuk mendapatkan fitur dari citra masukan. Kernel lazimnya berukuran ganjil karena terdapat pusat kernel yang akan diplot pada tiap index matriks citra masukan. Pengujian ini menggunakan dataset 8400 dengan perbandingan (splitting) tranning dan testing sebesar 70:30. Hasil dari penggunaan kernel 3x3 dan $5 \times 5$ dapat dilihat pada Tabel I.

TABEL I. PERFORMA PENGUJIAN TERHADAP UKURAN KERNEL

\begin{tabular}{|c|c|c|c|c|c|}
\hline $\begin{array}{c}\text { Ukuran } \\
\text { Kernel }\end{array}$ & $\begin{array}{c}\text { Akurasi } \\
\text { Training (\%) }\end{array}$ & $\begin{array}{c}\text { Akurasi Testing } \\
(\%)\end{array}$ & $\begin{array}{c}\text { Presisi } \\
(\%)\end{array}$ & $\begin{array}{c}\text { Recall } \\
(\%)\end{array}$ & $\begin{array}{c}\text { Waktu } \\
\text { komputasi (s) }\end{array}$ \\
\hline $\mathbf{3 \times 3}$ & 55.63 & 52,54 & 70.83 & 33.06 & 6,447 \\
\hline $\mathbf{5 x 5}$ & 63.89 & 55.48 & 68.74 & 39.52 & 8,493 \\
\hline
\end{tabular}


Berdasarkan Tabel I, didapatkan bahwa akurasi model dengan arsitektur menggunakan kernel konvolusi berukuran $5 \times 5$ memiliki performa yang lebih baik jika dibandingkan dengan kernel konvolusi berukuran $3 \times 3$. Model dengan arsitektur menggunakan kernel $5 \times 5$ memiliki akurasi sebesar $55.48 \%$, presisi $39.52 \%$, dan recall $39.52 \%$, sedangkan model dengan arsitektur $3 \times 3$ memiliki akurasi sebesar $52.54 \%$, presisi $70.83 \%$, dan recall 33.06\%. Dari hasil yang didapatkan kita juga bisa melihat bahwa makin kecil ukuran kernel maka presisi yang didapatkan makin besar namun recall yang didapatkan semakin kecil dan waktu komputasi yang dibutuhkan juga semakin sedikit. Model dengan arsitektur menggunakan kernel 5x5 menghabiskan waktu komputasi sebesar 8,493 detik sedangkan model dengan arsitektur $3 \times 3$ menghabiskan waktu komputasi sebesar 6,447 detik.

Arsitektur model yang semulanya menggunakan ukuran kernel 3x3 maka diganti dengan ukuran kernel $5 \times 5$, sehingga arsitektur model untuk pengujian parameter berikutnya yaitu menggunakan 3 layer konvolusi dimana masing-masing layer memiliki filter sebanyak 64, ukuran kernel 5x5, 1 HL dimana masingmasing layer memiliki neuron sebanyak 64,bobot dropout $20 \%$, learning rate 0.0001 , ukuran citra $32 \times 32$, metode normalisasi dengan fungsi aktivasi ReLU, dan 1 dimensi citra masukan (grayscale), dan dengan perbandingan data testing dan training 70:30

\subsection{Hasil Pengujian Terhadap Jumlah Filter Konvolusi}

Jumlah filter konvolusi merupakan banyaknya matrix yang menjadi pengali untuk mendapatkan fitur dari citra masukan matriks citra masukan. Pengujian ini menggunakan dataset 8400 dengan perbandingan (splitting) tranning dan testing sebesar 70:30. Hasil dari penggunaan filter konvolusi 32, 64, dan 128 dapat dilihat pada Tabel II.

TABEL II. PERFORMA PENGUJIAN TERHADAP FILTER KONVOLUSI

\begin{tabular}{|c|c|c|c|c|c|}
\hline $\begin{array}{c}\text { Jumlah } \\
\text { Filter }\end{array}$ & $\begin{array}{c}\text { Akurasi } \\
\text { Training (\%) }\end{array}$ & $\begin{array}{c}\text { Akurasi Testing } \\
\mathbf{( \% )}\end{array}$ & $\begin{array}{c}\text { Presisi } \\
\mathbf{( \% )}\end{array}$ & $\begin{array}{c}\text { Recall } \\
\mathbf{( \% )}\end{array}$ & $\begin{array}{c}\text { Waktu } \\
\text { komputasi (s) }\end{array}$ \\
\hline $\mathbf{3 2}$ & 54.15 & 50.60 & 68.86 & 27.02 & 6,265 \\
\hline $\mathbf{6 4}$ & 63.89 & 55.48 & 68.74 & 39.52 & 8,493 \\
\hline $\mathbf{1 2 8}$ & 73.66 & 60.32 & 68.79 & 52.66 & 20.701 \\
\hline
\end{tabular}

Berdasarkan Tabel II, didapatkan bahwa akurasi model dengan arsitektur menggunakan jumlah filter konvolusi sebesar 128 memiliki performa yang paling baik jika dibandingkan dengan jumlah filter konvolusi sebesar 64 dan 32. Model dengan jumlah filter konvolusi sebesar 128 memiliki akurasi sebesar $60.32 \%$, presisi $68.79 \%$, dan recall $52.66 \%$ sedangkan model dengan arsitektur 64 memiliki akurasi sebesar
$55.48 \%$, presisi $68.74 \%$, dan recall $39.52 \%$ dan arsitektur 32 memiliki akurasi sebesar $50.60 \%$, presisi $68.86 \%$, dan recall $27.02 \%$. Dari hasil yang didapatkan kita juga bisa melihat bahwa makin besar jumlah filter konvolusi maka recall yang didapatkan juga semakin tinggi namun jumlah filter konvolusi tidak mempengaruhi besarnya presisi yang didapatkan. Semakin besar jumlah filter konvolusi maka waktu komputasi yang dibutuhkan juga semakin tinggi. Model dengan arsitektur menggunakan filter konvolusi 128 menghabiskan waktu komputasi sebesar 20,701 detik sedangkan model dengan arsitektur 64 menghabiskan waktu komputasi sebesar 8,493 detik dan arsitektur 32 menghabiskan waktu komputasi sebesar 6,265 detik.

Arsitektur model yang semulanya menggunakan filter konvolusi 64 maka diganti dengan filter konvolusi 128, sehingga arsitektur model untuk pengujian parameter berikutnya yaitu menggunakan 3 layer konvolusi dimana masing-masing layer memiliki filter sebanyak 128 , ukuran kernel 5x5, 1 HL dimana masingmasing layer memiliki neuron sebanyak 64,bobot dropout 20\%, learning rate 0.0001 , ukuran citra $32 \times 32$, metode normalisasi dengan fungsi aktivasi ReLU, dan 1 dimensi citra masukan (grayscale), dan dengan perbandingan data testing dan training 70:30.

\subsection{Hasil Pengujian Terhadap Jumlah Hidden Layer}

Jumlah hidden layer dalam arsitektur neural network tidak memiliki ketetapan yang pasti. Semakin sedikit atau semakin banyaknya jumlah hidden layer yang digunakan dalam suatu model belum tentu menambah akurasi dari model yang dibangun. Oleh karena itu, penelitian ini menggunakan 3 variasi jumlah hidden layer sebagai parameter uji dengan hasil seperti pada Tabel III. Pengujian ini menggunakan dataset 8400 dengan perbandingan (splitting) tranning dan testing sebesar 70:30.

TABEL III. Performa PEnguJIAN terhadap hidDEN LAYER

\begin{tabular}{|c|c|c|c|c|c|}
\hline $\begin{array}{c}\text { Jumlah } \\
\text { Hidden Layer }\end{array}$ & $\begin{array}{c}\text { Akurasi } \\
\text { Training (\%) }\end{array}$ & $\begin{array}{c}\text { Akurasi Testing } \\
(\mathbf{\%})\end{array}$ & $\begin{array}{c}\text { Presisi } \\
(\mathbf{\%})\end{array}$ & $\begin{array}{c}\text { Recall } \\
(\mathbf{\%})\end{array}$ & $\begin{array}{c}\text { Waktu } \\
\text { komputasi (s) }\end{array}$ \\
\hline $\mathbf{1}$ & 73.66 & 60.32 & 68.79 & 52.66 & 20.701 \\
\hline $\mathbf{2}$ & 69.29 & 57.58 & 65.89 & 48.53 & 19,893 \\
\hline $\mathbf{3}$ & 55.00 & 52.46 & 70.00 & 32.78 & 18,686 \\
\hline
\end{tabular}

Berdasarkan Tabel III, didapatkan bahwa akurasi model dengan arsitektur menggunakan 1 hidden layer memiliki performa yang paling baik jika dibandingkan dengan 2 atau 3 hidden layer. Model dengan 1 hidden layer memiliki akurasi sebesar $60.32 \%$, presisi $68.79 \%$, dan recall $52.66 \%$ sedangkan model dengan 2 hidden layer memiliki akurasi sebesar $57.58 \%$, presisi $65.89 \%$, dan recall $48.53 \%$ dan 3 hidden layer memiliki akurasi sebesar $52.46 \%$, presisi $70 \%$, dan recall $32.78 \%$. Dari 
hasil yang didapatkan kita juga bisa melihat bahwa makin kecil jumlah hidden layer maka recall yang didapatkan semakin tinggi namun jumlah hidden layer tidak mempengaruhi besarnya presisi yang didapatkan. Semakin sedikit atau semakin banyaknya jumlah hidden layer yang digunakan dalam suatu model belum tentu menambah waktu komputasi yang dibutuhkan oleh model yang dibangun.

Arsitektur model yang semulanya menggunakan 1 hidden layer maka tetap menggunakan 1 hidden layer untuk pengujian parameter berikutnya, sehingga arsitektur model untuk pengujian parameter berikutnya yaitu menggunakan 3 layer konvolusi dimana masing-masing layer memiliki filter sebanyak 128, ukuran kernel 5x5, $1 \mathrm{HL}$ dimana masing-masing layer memiliki neuron sebanyak 64,bobot dropout $20 \%$, learning rate 0.0001 , ukuran citra $32 \times 32$, metode normalisasi dengan fungsi aktivasi ReLU, dan 1 dimensi citra masukan (grayscale), dan dengan perbandingan data testing dan training 70:30.

\subsection{Hasil Pengujian Terhadap Jumlah Neuron}

Sama halnya dengan jumlah hidden layer, jumlah neuron hidden layer tidak memiliki ketentuan tertentu. Pada ppenelitian ini, digunakan 3 variasi jumlah neuron untuk tiap hidden layarnya yaitu 32, 64, dan 128. Pengujian ini menggunakan dataset 8400 dengan perbandingan (splitting) tranning dan testing sebesar 70:30. Performa dari tiap variasi ukuran neuron disajikan pada Tabel IV.

TABEL IV. PERFORMA PENGUJIAN TERHADAP NEURON

\begin{tabular}{|c|c|c|c|c|c|}
\hline $\begin{array}{c}\text { Jumlah } \\
\text { Neuron }\end{array}$ & $\begin{array}{c}\text { Akurasi } \\
\text { Training (\%) }\end{array}$ & $\begin{array}{c}\text { Akurasi Testing } \\
(\%)\end{array}$ & $\begin{array}{c}\text { Presisi } \\
(\%)\end{array}$ & $\begin{array}{c}\text { Recall } \\
(\%)\end{array}$ & $\begin{array}{c}\text { Waktu } \\
\text { komputasi (s) }\end{array}$ \\
\hline $\mathbf{3 2}$ & 64.40 & 58.29 & 69.43 & 43.81 & 19,429 \\
\hline $\mathbf{6 4}$ & 73.66 & 60.32 & 68.79 & 52.66 & 20.701 \\
\hline 128 & 84.71 & 61.51 & 67.08 & 57.58 & 17,689 \\
\hline
\end{tabular}

Berdasarkan Tabel IV, didapatkan bahwa akurasi model dengan arsitektur menggunakan 128 neuron hidden layer memiliki performa yang paling baik jika dibandingkan dengan 32 atau 64 neuron hidden layer. Model dengan 128 neuron hidden layer memiliki akurasi sebesar $61.51 \% \%$, presisi $67.08 \%$, dan recall $57.58 \%$ sedangkan model dengan 32 neuron hidden layer memiliki akurasi sebesar $58.29 \% \%$, presisi $69.43 \%$, dan recall $43.81 \%$ dan 64 neuron hidden layer memiliki akurasi sebesar $60.32 \%$, presisi $68.79 \%$, dan recall 52.66\%. Dari hasil yang didapatkan dapat dilihat bahwa semakin sedikit jumlah neuron hidden layer yang digunakan maka presisi yang didapatkan semakin tinggi namun recall yang didapatkan semakin rendah. Semakin sedikit atau semakin banyaknya jumlah neuron hidden layer yang digunakan dalam suatu model belum tentu menambah waktu komputasi yang dibutuhkan oleh model yang dibangun.

Arsitektur model yang semulanya menggunakan 64 neuron hidden layer maka diganti dengan 128 neuron hidden layer, sehingga arsitektur model untuk pengujian parameter berikutnya yaitu menggunakan 3 layer konvolusi dimana masing-masing layer memiliki filter sebanyak 128, ukuran kernel 5x5, $1 \mathrm{HL}$ dimana masing-masing layer memiliki neuron sebanyak 128 , bobot dropout $20 \%$, learning rate 0.0001 , ukuran citra 32×32, metode normalisasi dengan fungsi aktivasi ReLU, dan 1 dimensi citra masukan (grayscale), dan dengan perbandingan data testing dan training 70:30.

\subsection{Hasil Pengujian Terhadap Bobot Dropout}

Dropout diterapkan pada model yang dibangun sebagai usaha untuk mengurangi terjadinya overfiting pada testing data (akurasi testing jauh lebih rendah dari training). Sama halnya dengan jumlah hidden layer dan neuron hidden layer, bobot dropout tidak memiliki ketentuan tertentu. Pada ppenelitian ini, digunakan 3 variasi bobot dropout untuk yaitu 20\%, 30\%, dan 50\%. Pengujian ini menggunakan dataset 8400 dengan perbandingan (splitting) tranning dan testing sebesar 70:30. Performa dari tiap variasi bobot dropout disajikan pada Tabel V.

TABEL V.PERFORMA PENGUJIAN TERHADAP DROPOUT

\begin{tabular}{|c|c|c|c|c|c|}
\hline $\begin{array}{c}\text { Bobot } \\
\text { Dropout (\%) }\end{array}$ & $\begin{array}{c}\text { Akurasi } \\
\text { Training (\%) }\end{array}$ & $\begin{array}{c}\text { Akurasi Testing } \\
\mathbf{( \% )}\end{array}$ & $\begin{array}{c}\text { Presisi } \\
(\mathbf{\%})\end{array}$ & $\begin{array}{c}\text { Recall } \\
(\mathbf{\%})\end{array}$ & $\begin{array}{c}\text { Waktu } \\
\text { komputasi (s) }\end{array}$ \\
\hline $\mathbf{2 0}$ & 84.71 & 61.51 & 67.08 & 57.58 & 17,689 \\
\hline $\mathbf{3 0}$ & 79.30 & 61.67 & 68.17 & 55.83 & 17,764 \\
\hline $\mathbf{5 0}$ & 66.16 & 59.37 & 71.05 & 48.21 & 20,871 \\
\hline
\end{tabular}

Berdasarkan Tabel V, didapatkan bahwa akurasi model dengan bobot dropout 30\% memiliki performa yang paling baik jika dibandingkan dengan $20 \%$ atau $50 \%$ bobot dropout. Model dengan bobot dropout $30 \%$ memiliki akurasi sebesar $61.67 \% \%$, presisi $68.17 \%$, dan recall $55.83 \%$ sedangkan model dengan bobot dropout $20 \%$ memiliki akurasi sebesar $61.51 \% \%$, presisi $67.08 \%$, dan recall $57.58 \%$ dan bobot dropout $50 \%$ memiliki akurasi sebesar $59.37 \%$, presisi $71.05 \%$, dan recall 48.21\%. Dari hasil yang didapatkan dapat dilihat bahwa semakin sedikit bobot dropout yang digunakan maka presisi yang didapatkan juga semakin rendah namun recall yang didapatkan semakin tinggi. Semakin sedikit atau semakin banyaknya bobot dropout yang digunakan dalam suatu model belum tentu menambah waktu komputasi yang dibutuhkan oleh model yang dibangun.

Arsitektur model yang semulanya menggunakan bobot dropout 20\% maka diganti dengan bobot dropout 30\%, sehingga arsitektur model untuk 
pengujian parameter berikutnya yaitu menggunakan 3 layer konvolusi dimana masing-masing layer memiliki filter sebanyak 128 , ukuran kernel $5 \times 5,1 \mathrm{HL}$ dimana masing-masing layer memiliki neuron sebanyak 128 ,bobot dropout $30 \%$, learning rate 0.0001 , ukuran citra 32×32, metode normalisasi dengan fungsi aktivasi ReLU, dan 1 dimensi citra masukan (grayscale), dan dengan perbandingan data testing dan training 70:30.

\subsection{Hasil Pengujian Terhadap Learning Rate}

Learning rate merupakan salah satu parameter training untuk menghitung nilai koreksi bobot pada waktu proses training. Dengan nilai $\alpha$ ini berada pada range nol sampai satu. Sama halnya dengan jumlah hidden layer dan neuron hidden layer, learning rate tidak memiliki ketentuan tertentu. Pada ppenelitian ini, digunakan 3 variasi learning rate 0.001 untuk yaitu $0.01,0.001$, dan 0.0001. Pengujian ini menggunakan dataset 8400 dengan perbandingan (splitting) tranning dan testing sebesar 70:30. Performa dari tiap variasi learning rate disajikan pada Tabel VI

TABEL VI. Performa Pengujian terhadap learning Rate

\begin{tabular}{|c|c|c|c|c|c|}
\hline $\begin{array}{c}\text { Learning } \\
\text { Rate }\end{array}$ & $\begin{array}{c}\text { Akurasi } \\
\text { Training (\%) }\end{array}$ & $\begin{array}{c}\text { Akurasi Testing } \\
\mathbf{( \% )}\end{array}$ & $\begin{array}{c}\text { Presisi } \\
\mathbf{( \% )}\end{array}$ & $\begin{array}{c}\text { Recall } \\
\mathbf{( \% )}\end{array}$ & $\begin{array}{c}\text { Waktu } \\
\text { komputasi (s) }\end{array}$ \\
\hline $\mathbf{0 . 0 1}$ & 2.96 & 3.57 & 0.00 & 0.00 & 17,532 \\
\hline $\mathbf{0 . 0 0 1}$ & 98.13 & 67.22 & 68.37 & 66.83 & 17,987 \\
\hline $\mathbf{0 . 0 0 0 1}$ & 79.30 & 61.67 & 68.17 & 55.83 & 17,764 \\
\hline
\end{tabular}

Berdasarkan Tabel VI, didapatkan bahwa akurasi model dengan learning rate 0.001 memiliki performa yang paling baik jika dibandingkan dengan learning rate 0.01 atau 0.0001 . Model dengan learning rate 0.001 memiliki akurasi sebesar $67.22 \%$, presisi $68.37 \%$, dan recall $66.83 \%$ sedangkan model dengan learning rate 0.01 memiliki akurasi sebesar $3.57 \%$ presisi $0 \%$, dan recall $0 \%$ dan learning rate 0.0001 memiliki akurasi sebesar $61.67 \%$ presisi $68.17 \%$, dan recall $55.83 \%$. Dari hasil yang didapatkan dapat dilihat bahwa model dengan learning rate terlalu rendah mendapatkan presisi dan recall sebesar $0 \%$. Semakin sedikit atau semakin banyaknya learning rate yang digunakan dalam suatu model belum tentu menambah waktu komputasi yang dibutuhkan oleh model yang dibangun.

Arsitektur model yang semulanya menggunakan learning rate 0.0001 maka diganti dengan learning rate 0.001 , sehingga arsitektur model untuk pengujian parameter berikutnya yaitu menggunakan 3 layer konvolusi dimana masing-masing layer memiliki filter sebanyak 128, ukuran kernel 5x5, $1 \mathrm{HL}$ dimana masingmasing layer memiliki neuron sebanyak 128,bobot dropout $30 \%$, learning rate 0.001 , ukuran citra $32 \times 32$, metode normalisasi dengan fungsi aktivasi ReLU, dan 1 dimensi citra masukan (grayscale), dan dengan perbandingan data testing dan training 70:30.

\subsection{Hasil Pengujian Terhadap Perbandingan Data Training dan Testing}

Sama halnya dengan jumlah hidden layer dan neuron hidden layer, perbandingan data training dan testing tidak memiliki ketentuan tertentu. Pada ppenelitian ini, digunakan 2 variasi perbandingan data training dan testing yaitu 70:30 dan 80:20. Pengujian ini menggunakan dataset 8400 dengan perbandingan (splitting) tranning dan testing sebesar 70:30. Performa dari tiap variasi perbandingan data training dan testing disajikan pada Tabel VII

TABEL VII. PeRforma PENGUJIAN teRHAdAP PERBANDINGAN DATA

\begin{tabular}{|c|c|c|c|c|c|}
\hline Perbandingan & $\begin{array}{c}\text { Akurasi } \\
\text { Training (\%) }\end{array}$ & $\begin{array}{c}\text { Akurasi Testing } \\
(\%)\end{array}$ & $\begin{array}{c}\text { Presisi } \\
(\%)\end{array}$ & $\begin{array}{c}\text { Recall } \\
(\%)\end{array}$ & $\begin{array}{c}\text { Waktu } \\
\text { komputasi (s) }\end{array}$ \\
\hline $80: 20$ & 97.50 & 66.07 & 67.14 & 65.30 & 21,935 \\
\hline $70: 30$ & 98.13 & 67.22 & 68.37 & 66.83 & 17,987 \\
\hline
\end{tabular}

Berdasarkan Tabel VII, didapatkan bahwa akurasi model dengan perbandingan data training dan testing 70:30 memiliki performa yang paling baik jika dibandingkan dengan perbandingan data training dan testing 80:20. Model dengan perbandingan data training dan testing 70:30 memiliki akurasi sebesar $67.22 \%$ presisi $68.37 \%$, dan recall $66.83 \%$ sedangkan model dengan perbandingan data training dan testing 80:20 memiliki akurasi sebesar $66.07 \%$ presisi $67.14 \%$, dan recall $65.30 \%$. Semakin banyaknya data testing yang digunakan dalam suatu model maka makin tinggi juga presisi dan recall yang didapatkan namun waktu komputasi yang dibutuhkan juga semakin banyak. Model dengan perbandingan data training dan testing 70:30 membutuhkan waktu komputasi sebanyak 17,987 sedangkan model dengan perbandingan data training dan testing 80:20 membutuhkan waktu komputasi sebanyak 21,935.

Arsitektur model yang semulanya menggunakan perbandingan data training dan testing 70:30 maka tetap menggunakan perbandingan data training dan testing 70:30, sehingga arsitektur model untuk pengujian parameter berikutnya yaitu menggunakan 3 layer konvolusi dimana masing-masing layer memiliki filter sebanyak 128, ukuran kernel 5x5, $1 \mathrm{HL}$ dimana masing-masing layer memiliki neuron sebanyak 128 ,bobot dropout $30 \%$, learning rate 0.001 , ukuran citra 32×32, metode normalisasi dengan fungsi aktivasi ReLU, dan 1 dimensi citra masukan (grayscale), dan dengan perbandingan data testing dan training 70:30. 


\subsection{Hasil Pengujian Terhadap Ukuran Citra Masukan}

Ukuran citra merupakan bagian yang diatur di dalam persiapan sebelum melakukan proses training atau bisa disebut sebagai bagian yang ditentukan pada tahap pre-processing. Semakin kecil ukuran citra maka detail dari citra itu sendiri semakin tidak terlihat. pada penelitian ini akan uji 3 ukuran citra yaitu $32 \times 32,64 \times 64$, dan 96x96. Pengujian ini menggunakan dataset 8400 dengan perbandingan (splitting) tranning dan testing sebesar 70:30. Performa dari tiap ukuran citra masukan disajikan pada Tabel VIII.

TABEL VIII. PERFORMA PENGUJIAN TERHADAP UKURAN CITRA

\begin{tabular}{|c|c|c|c|c|c|}
\hline Ukuran Citra & $\begin{array}{c}\text { Akurasi } \\
\text { Training (\%) }\end{array}$ & $\begin{array}{c}\text { Akurasi Testing } \\
(\%)\end{array}$ & $\begin{array}{c}\text { Presisi } \\
(\%)\end{array}$ & $\begin{array}{c}\text { Recall } \\
(\%)\end{array}$ & $\begin{array}{c}\text { Waktu } \\
\text { komputasi (s) }\end{array}$ \\
\hline $32 \times 32$ & 98.13 & 67.22 & 68.37 & 66.83 & 17,987 \\
\hline $64 \times 64$ & 98.10 & 78.10 & 79.68 & 77.82 & 56,706 \\
\hline $\mathbf{9 6 x 9 6}$ & 98.15 & 74.52 & 76.60 & 73.77 & 130,819 \\
\hline
\end{tabular}

Berdasarkan Tabel VIII, didapatkan bahwa akurasi model dengan ukuran citra masukan $64 \times 64$ memiliki performa yang paling baik jika dibandingkan dengan ukuran citra masukan 32×32 dan 96x96. Model dengan ukuran citra masukan $64 \times 64$ memiliki akurasi sebesar $78.10 \%$, presisi $79.68 \%$, dan recall $77.82 \%$ sedangkan model dengan ukuran citra masukan $32 \times 32$ memiliki akurasi sebesar $67.22 \%$, presisi $68.37 \%$, dan recall $66.83 \%$ dan model dengan ukuran citra masukan $96 \times 96$ memiliki akurasi sebesar $74.52 \%$, presisi $76.60 \%$, dan recall $73.77 \%$.Dari hasil yang didapatkan kita bisa melihat bahwa makin besar kecilnya ukuran citra tidak mempengaruhi presisi dan recall yang didapatkan. Semakin besar ukuran citra masukan yang digunakan dalam suatu model maka makin banyak juga waktu komputasi yang dibutuhkan. Model dengan ukuran citra masukan $32 \times 32$ membutuhkan waktu komputasi sebanyak 17,987 detik sedangkan model dengan dengan ukuran citra masukan 64x64 membutuhkan waktu komputasi sebanyak 56,706 detik dan model dengan dengan ukuran citra masukan 96x96 membutuhkan waktu komputasi sebanyak 130,819 detik.

Arsitektur model yang semulanya ukuran citra masukan $32 \times 32$ maka diganti dengan ukuran citra masukan 64x64, sehingga menghasilkan arsitektur model dengan menggunakan 3 layer konvolusi dimana masing-masing layer memiliki filter sebanyak 128, ukuran kernel 5x5, $1 \mathrm{HL}$ dimana masing-masing layer memiliki neuron sebanyak 128 ,bobot dropout $30 \%$, learning rate 0.001 , ukuran citra $64 \times 64$, metode normalisasi dengan fungsi aktivasi ReLU, dan 1 dimensi citra masukan (grayscale), dan dengan perbandingan data testing dan training 70:30.

\subsection{Hasil Pengujian Terhadap Epoch}

Satu kali Epoch adalah ketika semua dataset melewati satu kali proses forward dan backward melewati semua node neural network 1 kali. Semakin banyaknya epoch, maka semakin sering weight yang ada pada neural di-update. Semakin banyak epoch yang digunakan tentu semakin banyak juga waktu yang dibutuhkan model. Akan tetapi semakin sedikit atau semakin banyaknya batas epoch yang digunakan dalam suatu model belum tentu menambah akurasi dari model yang dibangun Pada penelitian ini akan uji 3 variasi batas epoch yaitu 100, 500, dan 1000.

Pada pengujian terhadap batas epoch arsitektur model yang digunakan berbeda dari arsitektur model yang digunakan untuk menguji parameter sebelumnya. Mengingat dari hasil pengujian sebelumnya yang menunjukkan besarnya ukuran kernel, jumlah filter konvolusi, dan ukuran citra masukan sangat mempengaruhi waktu komputasi, maka dikarenakan keterbatasan resource besarnya ukuran kernel, jumlah filter konvolusi, dan ukuran citra masukan yang dignakan dalam pengujian ini adalah yang paling sedikit memakan waktu komputasi. Sehingga arsitektur model yang digunakan arsitektur model dengan menggunakan 3 layer konvolusi dimana masing-masing layer memiliki filter sebanyak 32, ukuran kernel $3 \times 3,1 \mathrm{HL}$ dimana masing-masing layer memiliki neuron sebanyak 128 ,bobot dropout $30 \%$, learning rate 0.001 , ukuran citra $32 \times 32$, metode normalisasi dengan fungsi aktivasi ReLU, dan 1 dimensi citra masukan (grayscale), dan dengan perbandingan data testing dan training 70:30. Performa dari tiap variasi batas epoch disajikan pada Tabel IX.

Berdasarkan Tabel IX, didapatkan bahwa akurasi model dengan batas epoch 500 memiliki performa yang paling baik jika dibandingkan dengan batas epoch 100 dan 1000. Model dengan batas epoch 500 memiliki akurasi sebesar $66.23 \%$, presisi $66.23 \%$, dan recall $65.79 \%$ sedangkan model dengan batas epoch 100 memiliki akurasi sebesar $65.52 \%$, presisi $66.65 \%$, dan recall $64.09 \%$ dan model dengan batas epoch 1000 memiliki akurasi sebesar $62.42 \%$, presisi $63.11 \%$, dan recall $62.26 \%$.

TABEL IX. Performa Pengujian terhadap EPOCH

\begin{tabular}{|c|c|c|c|c|c|}
\hline Ukuran Citra & $\begin{array}{c}\text { Akurasi } \\
\text { Training (\%) }\end{array}$ & $\begin{array}{c}\text { Akurasi Testing } \\
\mathbf{( \% )}\end{array}$ & $\begin{array}{c}\text { Presisi } \\
\mathbf{( \% )}\end{array}$ & $\begin{array}{c}\text { Recall } \\
\mathbf{( \% )}\end{array}$ & $\begin{array}{c}\text { Waktu } \\
\text { komputasi (s) }\end{array}$ \\
\hline $\mathbf{1 0 0}$ & 95,60 & 65,52 & 66,65 & 64,09 & 11.006 \\
\hline $\mathbf{5 0 0}$ & 99,06 & 66,23 & 67,07 & 65,79 & 44.596 \\
\hline $\mathbf{1 0 0 0}$ & 99,47 & 62,42 & 63,11 & 62,26 & 97.918 \\
\hline
\end{tabular}


Semakin besar batas epoch yang digunakan dalam suatu model tidak mempengaruhi presisi dan recall yang didapatkan namun tetunya besar batas epoch maka makin banyak juga waktu komputasi yang dibutuhkan. Model dengan dengan batas epoch 100 membutuhkan waktu komputasi sebanyak 11,006 detik sedangkan model dengan dengan batas epoch 500 membutuhkan waktu komputasi sebanyak 44,596 detik dan model dengan dengan batas epoch 1000 membutuhkan waktu komputasi sebanyak 97,918 detik.

\subsection{Pengujian Model pada Datasets 8400 Citra}

Pengujian ini menggunakan model terbaik yang telah didapatkan sebelumnya, yaitu model dengan menggunakan 3 layer konvolusi dimana masing-masing layer memiliki filter sebanyak 128, ukuran kernel 5x5, $1 \mathrm{HL}$ dimana masing-masing layer memiliki neuron sebanyak 128 , bobot dropout $30 \%$, learning rate 0.001 , ukuran citra $64 \times 64$, metode normalisasi dengan fungsi aktivasi ReLU, dan 1 dimensi citra masukan (grayscale), dan dengan perbandingan data testing dan training 70:30.

Model akan diuji untuk mencoba melakukan klasifikasi aksara Arab yang berbeda dari dataset yang digunakan untuk pelatihan model yaitu dataset 16800 citra yang merupakan dataset dari penelitian sebelumnya[8] dan model juga akan diuji untuk mencoba melakukan klasifikasi aksara Arab dengan gabungan dari dua dataset yang berbeda yaitu dari dataset 16800 citra yang merupakan dataset dari penelitian sebelumnya ditambah dataset 8400 citra yang merupakan dataset yang diambil oleh peneliti.

Berdasarkan Tabel $\mathrm{X}$ dapat diihat bahwa model yang telah didapatkan dapat mengklasifikasi dataset 8400 citra dengan baik dengan akurasi $78.10 \%$, presisi $79.68 \%$, dan recall $77.82 \%$. Model dapat melakukan klasifikasi dengan peforma yang sangat baik terhadap dataset 16800 dengan akurasi $92.64 \%$, presisi $93.29 \%$, dan recall $92.40 \%$.

\section{TABEL X.PERFORMA PENGUJIAN TERHADAP DATASET}

\begin{tabular}{|c|c|c|c|c|c|}
\hline Dataset & $\begin{array}{c}\text { Akurasi } \\
\text { Training (\%) }\end{array}$ & $\begin{array}{c}\text { Akurasi } \\
\text { Testing (\%) }\end{array}$ & Presisi (\%) & Recall (\%) & $\begin{array}{c}\text { Waktu } \\
\text { komputasi (s) }\end{array}$ \\
\hline $\mathbf{8 4 0 0}$ & 98,10 & 78,10 & 79,68 & 77,82 & 56.706 \\
\hline $\mathbf{1 6 8 0 0}$ & 99,52 & 92,64 & 93,29 & 92,40 & 109.155 \\
\hline $\mathbf{2 5 2 0 0}$ & 98,49 & 69,76 & 71,44 & 69,18 & 93.128 \\
\hline
\end{tabular}

Model mendapatkan peforma terendah pada dataset 25200 dengan akurasi $69.76 \%$, presisi $71.44 \%$, dan recall $69.18 \%$.Hasil pengujian menunjukkan bahwa dataset 8400 citra mendapatkan akurasi yang lebih rendah dari pengujian dataset 16800 citra. Hal ini disebabkan kategori dataset 8400 citra memiliki dua kategori yaitu dari anak-anak dan dewasa yang memiliki bentuk tulisan tangan yang sangat jauh berbeda serta pre-processing dataset 8400 citra masih belum cukup baik dibandingkan dataset 16800 citra, hal ini dapat dilihat pada skala citra pada dataset 8400 yang memiliki skala yang berbeda beda, sedangkan dataset 16800 memiliki skala citra yang seragam. Peforma model pada dataset 25200 citra paling rendah karena dataset berasal dari gabungan dataset yang berbeda.

\section{KESIMPULAN DAN SARAN}

\subsection{Kesimpulan}

Berdasarkan penelitian yang sudah dilakukan, terdapat beberapa hal yang bisa penulis simpulkan antara lain sebagai berikut.

1. Model yang dihasilkan pada penelitian ini menggunakan 3 layer konvolusi dimana masingmasing layer memiliki filter sebanyak 128 , ukuran kernel $5 \times 5,1 \mathrm{HL}$ dimana masing-masing layer memiliki neuron sebanyak 128,bobot dropout $30 \%$, learning rate 0.001 , ukuran citra $64 \times 64$, metode normalisasi dengan fungsi aktivasi ReLU, dan 1 dimensi citra masukan (grayscale), dan dengan perbandingan data testing dan training 70:30.

2. Persentasi tertinggi pada model ini yaitu $78.10 \%$. Hal ini membuktikan bahwa metode usulan memiliki potensi yang baik untuk dikembangkan sebagai media pembelajaran Aksara Arab.

3. Ukuran citra masukan terbaik pada pengujian ini yaitu 64x64, dimana semakin besar ukuran citra masukan maka dapat semakin lama juga proses komputasi yang dibutuhkan.

4. Meningkatkan jumlah epoch pada proses training model tidak dapat menjamin akurasi model meningkat.

Model terbaik yang didapatkan oleh peneliti dapat melakukan klasifikasi dengan baik pada data penelitian sebelumnya

\subsection{Saran}

Ada beberapa saran yang dapat penulis berikan apabila penelitian ini akan dikembangkan kembali antara lain sebagai berikut.

1. Persiapan sebelum penelitian seperti pengambilan data harus diperhatikan untuk mendapatkan data penelitian yang bagus seperti variasi dataset dan ketebalan tulisan tangan.

2. Menggunakan metode augmentasi yang merupakan salah satu metode untuk menduplikat data citra sehingga mendapatkan data citra yang lebih banyak 


\section{DAFTAR PUSTAKA}

[1] E. Nuranti Kusuma, "Identifikasi Citra Huruf Arab Menggunakan Metode Jaringan Syaraf Tiruan Kohonen." Universitas Islam Negeri Maulana Malik Ibrahim, Malang, 2015.

[2] A. Mustofa, "Bagaimana Cara Belajar Bahasa Arab yang Baik," 2018. [Online]. Available: https://www.kompasiana.com/abdulmustofa528 3/5c016c5eaeebe15d8e66c697/bagaimana-carabelajar-bahasa-arab-yang-baik.

[3] Sam'ani and M. H. Qamaruzzaman, "Pengenalan Huruf Dan Angka Tulisan Tangan Mengunakan Metode Convolution Neural Network (CNN)," J. Speed - Sent. Penelit. Eng. dan Edukasi, vol. 9, no. 2, pp. 5-64, 2017.

[4] M. Zulfar and B. Setiyono, "Convolutional Neural Networks untuk Pengenalan Wajah Secara Real Time," J. Sains dan Seni ITS, vol. 5, no. 2, pp. 7277, 2016.

[5] J. Pujoseno, "Implementasi Deep Learning Menggunakan Convolution Neural Network untuk Klasifikasi Alat Tulis." Universitas Islam Indonesia, Yogyakarta, pp. 6-59, 2018.

[6] H. Andriani, "Pengenalan Tulisan Tangan pada Lembar Ujian Pilihan Ganda Menggunakan Metode Convolutional Neural Network." Universitas Pendidikan Indonesia, Bandung, 2019.

[7] N. Hasbah, R. Roth, "Using Deep Morphology to Improve Automatic Error Detection in Arabic Handwritten Recognition," Association for Computational Linguistics., pp. 875-884, 2011

[8] H. Althobaiti, C. Lu, "Isolated Handwritten Arabic Character Recognition Using Freeman Chain Code and Tangent Line," Association for Computing Machinery., pp. 79-84, 2017.

[9] A. El-Sawy, M. Loey, and H. El-Bakry, "Arabic Handwritten Characters Recognition using Convolutional Neural Network," WSEAS Trans. Comput. Res., vol. 5, pp. 11-19, 2017.

[10] I. W. Suartika Eka Putra, A. Yudhi Wijaya, and R. Soelaiman, "Klasifikasi Citra Menggunakan Convolutional Neural Network ( Cnn ) pada Caltech 101," J. Tek. ITS, vol. 5, no. 1, pp. A65-A69, 2016.
[11] I. W. Suartika Eka Putra, "Klasifikasi Citra Menggunakan Convolutional Neural Network (CNN) pada Caltech 101." Institut Teknologi Sepuluh Nopember Surabaya, Surabaya, pp. 1-59, 2016.

[12] Vidia, "Pengenalan Tulisan Tangan Bahasa Arab Menggunakan Metode Probabilistic Neural Network," J. Ilmu Komput. dan Desain Komun. Vis., vol. 4, no. 1, pp. 28-35, 2019.

[13] I. Faturrahman, Arini, and F. Mintarsih, "Pengenalan pola huruf hijaiyah khat kufi dengan metode deteksi tepi sobel berbasis jaringan syaraf tiruan backpropagation," J. Tek. Inform., vol. 11, no. 1, pp. 37-46, 2018.

[14] A. Perwira Joan Dwitama, "Klasifikasi Tingkat Retakan Pada Bangunan Berbasis Citra Menggunakan Metode Convolution Neural Network." Universitas Mataram, Mataram, 2019.

[15] Y. LeCun, K. Kavukcuoglu, and C. Farabet, "Convolutional Networks and Applications in Vision," ISCAS 2010 - 2010 IEEE Int. Symp. Circuits Syst. Nano-Bio Circuit Fabr. Syst., pp. 253-256, 2010.

[16] S. Sena, "Pengenalan Deep Learning Part 7 : Convolutional Neural Network (CNN)," 2017. [Online]. Available: https://medium.com/@samuelsena/pengenalandeep-learning-part-7-convolutional-neuralnetwork-cnn-b003b477dc94. [Accessed: 16-Apr2020].

[17] Salsabila, "Penerapan Deep Learning Menggunakan Convolutional Neutral Network untuk Klasifikasi Citra Wayang Punakawan." Universitas Islam Indonesia, Yogyakarta, 2018.

[18] M. Cahaya Dewi Ratnasari, “Deep Learning Convolution Neural Network untuk Klasifikasi Pengenalan Objek Menggunakan MXNET." Universitas Islam Indonesia, Yogyakarta, 2018.

[19] C. K. Dewa, A. L. Fadhilah, and A. Afiahayati, "Convolutional Neural Networks for Handwritten Javanese Character Recognition," IJCCS (Indonesian J. Comput. Cybern. Syst., vol. 12, no. 1, p. 83, 2018. 